\title{
THE EFFECT OF RECIPROCAL TEACHING STRATEGY ON STUDENTS' READING COMPREHENSION IN NARRATIVE TEXT AT GRADE IX OF SMP N 5 PANYABUNGAN
}

\author{
NUR INAYAH HASIBUAN \\ IAIN Padangsidimpuan
}

\begin{abstract}
Abstrak
Penelitian ini adalah tentang pengaruh strategi pengajaran resiprokal pada pemahaman membaca siswa dalam teks naratif di kelas IX SMP N 5 Panyabungan. Permasalahan dalam penelitian ini adalah sebagian besar siswa masih mendapat nilai rendah sekitar 70 dalam mata pelajaran bahasa Inggris terutama pemahaman membaca dan siswa kurang minat membaca dan tidak memahami teks dengan baik serta mereka juga membuang waktu untuk mendapatkan makna dalam kamus; akhirnya sebagian besar siswa gagal dalam pemahaman membaca. Tujuan dari penelitian ini adalah untuk menguji pengaruh yang signifikan dari strategi pengajaran resiprokal terhadap pemahaman membaca siswa dalam teks naratif di kelas IX SMP N 5 Panyabungan. Penelitian ini telah dilaksanakan dengan penelitian eksperimental. Populasi penelitian ini adalah siswa kelas IX SMP N 5 Panyabungan. Total populasi adalah delapan kelas. Kemudian, sampel dibagi menjadi dua kelas. Kelas pertama (dua puluh dua siswa) sebagai kelas eksperimen, sedangkan kelas kedua (sembilan belas siswa) sebagai kelas kontrol. Untuk mengumpulkan data, peneliti menggunakan tes untuk mengukur Pemahaman Membaca Siswa. Untuk menganalisis data, peneliti menggunakan uji-t. Analisis data post-test menunjukkan bahwa skor siswa di kelas eksperimen secara signifikan lebih tinggi daripada skor siswa di kelas kontrol pada tingkat signifikansi 5\% dengan tingkat kebebasan $(n 1+n 2-2)=39$. Nilai rata-rata didapat di kelas eksperimen adalah 73,09, skor tertinggi adalah 92 dan skor terkecil adalah 40 . Sementara, nilai rata-rata yang didapat di kelas kontrol adalah 63,78, skor tertinggi adalah 88 dan skor terkecil adalah 40. tcount dari observasi adalah 2.75 Sedangkan ttable adalah 1.682. Oleh karena itu, hipotesis diterima. Jadi, ada pengaruh yang signifikan dari Strategi Mengajar Timbal Balik pada Pemahaman Membaca Siswa dalam Teks Naratif di Kelas IX SMP N 5 Panyabungan.
\end{abstract}

Kata Kunci: Resiprokal, Pemahaman Membaca, Naratif Teks, SMP N5 Panyabungan 


\begin{abstract}
This research focused about the effect of reciprocal teaching strategy on students' reading comprehension in narrative text at grade IX of SMP N 5 Panyabungan. The problems of this research were most of the students still got low score about 70 in English subject especially reading comprehension and the students had lack of reading interest and did not understand text well and also they wasted time to get the meaning in dictionary; finally most of the students failed in reading comprehension. The aim of this research was to examine the significant effect of reciprocal teaching strategy on students' reading comprehension in narrative text at grade IX of SMP N 5 Panyabungan. This research has been done by experimental research. The population of this research was the grade IX of SMP N 5 Panyabungan. The total of population were eight classes. Then, the sample was divided into two classes. The first class (twenty two students) as the experimental class, while the second class (nineteen students) as the control class. To collect the data, researcher used test for measuring Students' Reading Comprehension. To analyze the data, the researcher used t-test. Data analysis of the post-test showed that score of the students in the experimental class was significantly higher than score of the students in the control class at the level of significance $5 \%$ with degree of freedom $\left(n_{1}+n_{2}-2\right)=39$. Mean score was got in the experimental class is 73.09, highest score is 92 and smallest score is 40 . While, mean score was got in the control class is 63.78 , highest score is 88 and smallest score is 40 . The $t_{\text {count }}$ of observation is 2.75 while the $t_{\text {table }}$ is 1.682. Therefore, the hypothesis was accepted. So, there was significant effect of Reciprocal Teaching Strategy on Students' Reading Comprehension in Narrative Text at Grade IX of SMP N 5 Panyabungan.

Keywoard: Reciprocal, Reading Comprehension, Narrative Text, SMP N5 Panyabungan
\end{abstract}

\title{
INTRODUCTION
}

In Indonesia, the needed of English as foreign language has developed. It is an instrument to transfer modern knowledge, culture, and to grow up International relation. International language is the concept of the English as a global means of communication in numerous dialects, and also the movement towards an International standard for the language. ${ }^{1}$ Realizing how important this language, our government had determined English as the first foreign

${ }^{1}$ M.F. Patel \& Praveen M. Jain, English Language Teaching (Methods, Tools, E Technique), (Jaipur: Sunrise Publishers \& Distributers), p.6. 
language which taught in Indonesia. By English, the students are hoped to enrich their knowledge, so they are able to apply their knowledge in the life.

Then, the students are passive in the class, it caused the strategy of teaching is not suitable. The teachers usually teach reading comprehension by translating the text or use conventional strategy. Therefore, the students always open the dictionary when they want to find out the main idea of the reading text. So, students and teacher must have reading strategy to be easier and better to comprehend the text, because reading strategy is important for student and teacher.

Based on the explanation above, researcher can made inference that reading very important in our live especially for students. However, the reading is still a big problem at SMP Negeri 5 Panyabungan. The interesting of student English study are low, especially students' reading comprehension in narrative text.

To solve the problem in reading, there are some alternative of reading strategies that are available and applicable. As researcher knew that there are many strategies that can solve students' problem in reading comprehension, and also can increased the students' ability in reading, such as Skimming, Scanning, Silent Reading, P2R (Preview Read Review), SQ3R (Survey, Question, Read, Recite, and Review), and Reciprocal Teaching Strategy.

From the explanation above, the researcher chose reciprocal teaching strategy. Reciprocal teaching strategy is an excellent learning strategy that is found to be effective in improving the reading and comprehension skills of young students. Annemarie Sullivan Palincsar said "Reciprocal teaching is best represented as a dialog between teachers and student in which participants take turns assuming the role of teacher". ${ }^{2}$ Then, Reciprocal teaching is based on Vygotsky's theory of the fundamental role of social interaction (dialog) in the development of cognition. Thinking aloud and discussion of thoughts aid in clarification and revision of thinking and learning, therefore developing cognition. ${ }^{3}$ While, Brown stated "the strategies embedded in reciprocal teaching represent those that successful learners engage in while interacting with text". ${ }^{4}$

${ }^{2}$ Uttara Manohar, “Reciprocal Teaching” retrieved http://www.buzzle.com/articles/reciprocalteaching-strategies.html accessed on Monday, 30 th April 2015.

3 L. S. Vygotsky, Mind in Society: The development of the higher psychological process, (Cambridge, MA: The Harvard University Press, 1978), p. 86.

4 A. L. Brown, Metacognitive Development and Reading. In R.S. Spiro, B.B. Bruce \& W.L. Brewer (Eds), Theorotical Issues in Reading Comprhension, (Hillsdace, Ng: Erlboum, 1980), p. 67. 
254 | TAZKIR: Jurnal Penelitian Ilmu-ilmu Sosial dan Keislaman

Vol. 03 No. 2 Desember 2017

So, reciprocal teaching is a strategy that asks students and teachers to share the role of teacher by allowing both to lead the discussion about a given reading.

The view of above explanation and reasons, the researcher interested in conducting experimental research of which purpose to solve student's problem in reading comprehension by title "The Effect of Reciprocal Teaching Strategy on Students' Reading Comprehension in Narrative Text at Grade IX Student of SMP Negeri 5 Panyabungan". The researcher explored the difference of reading achievement after applying the strategies in the classroom.

\section{FORMULATION OF THE PROBLEM}

The formulation of the problem "was there the significant effect of using reciprocal teaching strategy on students' reading comprehension in narrative text at grade IX of SMP Negeri 5 Panyabungan?"

\section{THEORETICAL DESCRIPTION}

Theories were very necessary for explaining some concepts or terms applied in research. The theories are as follows:

\section{Description of Reciprocal Teaching Strategy}

a. Definition of Reciprocal Teaching Strategy

At the first time, applying reciprocal teachings the teacher informs about introduce a learning approach/strategy; explain the purpose, benefit and procedure. Then, start from modeling of read a paragraph a reading. Then, explain and teach that during or after read there are activities that must be done. They are:

1) Think the important questions that can be asked from what have you read; appropriate with the reading; and believing can answering;

2) Make summarizing about the most information from the reading;

3) Predict what will the impossible to discussed continue: and

4) Write if there are unclear things or not logic from a part, then check what we can be success to make logic things. ${ }^{5}$

After the students understand skill above the teacher will show a student to change the role in the group. The first showed the student as a leader of discussion, then in sequence every students feel/do role as

5 Trianto, Mendesain Model Pembelajaran Inovatif-Progresif, (Jakarta: Kencana Prenada Media Group, 2009), p. 174. 
teacher. After the introduction is over, the teacher explains to student why, when, and how the strategy is used.

Annemarie Sullivan Palincsar explains "Reciprocal teaching is best represented as a dialog between teachers and students in which participants take turns assuming the role of teacher". ${ }^{6}$ While, Brown stated "the strategies embedded in reciprocal teaching represent those that successful learners engage in while interacting with text". ${ }^{7}$ So, it can be concluded that reciprocal teaching is an excellent learning strategy that is found to be effective in improving the reading and comprehension skills of young students.

Reciprocal teaching is an approach to student teaching in learning strategies. It is a constructive approach that based on Principe of making/question generating, where the metacognitive skills is taught through direct instruction and training model by teacher to revise doing student reading comprehension is low. Reciprocal teaching especially built to help the teacher use together conversation to teach reading comprehension independently at the class. ${ }^{8}$ So, reciprocal teaching is an approach in student teaching.

Reciprocal Teaching can be used during read-aloud, shared and guided reading, and literature circles. Students learn the strategies through teacher modeling and think-aloud so that they can eventually take turns coaching other students through the process. Following the Gradual Release of Responsibility Model, only with student understand and use the four comprehension strategies with support should they be expected to apply them independently. ${ }^{9}$ So, the researcher concluded that the reciprocal teaching strategy is a good strategy to get or find out the information and ideas from the text.

b. Procedure of Reciprocal Teaching Strategy

In the next stage reciprocal teaching through daily procedure such as:

6Uttara Manohar, "Reciprocal Teaching” retrieved http://www.buzzle.com/articles/reciprocalteaching-strategies.html, accessed on Monday, 30 th April 2015.

7 A. L. Brown, Metacognitive Development and Reading. In R.S. Spiro, B.B. Bruce \& W.L. Brewer (Eds), Theorotical Issues in Reading Comprhension, (Hillsdace, Ng: Erlboum, 1980), p. 67.

${ }^{8}$ Trianto, Mendesain Model... p. 173.

${ }_{9}$ Miriam P. Trehearne and Roz Doctorow, Reading Comprehension: Strategies That Work, (Newark: DE International Reading Association, 2000), p. 169. 
256 | TAZKIR: Jurnal Penelitian Ilmu-ilmu Sosial dan Keislaman

Vol. 03 No. 2 Desember 2017

1) Prepared reading text based on materiel that finished.

2) Explained that the first stage the teacher as act teacher (model).

3) Student is asked to silent read part of reading that chosen. To make easy do it paragraph by paragraph firstly.

4) If student had finished first part, done the models are:

a) The question that I think will ask the teacher.

b) Teacher gives opportunity student to answer the question.

c) Summarize main idea in the paragraph.

d) Give opportunity student to predict thing will be discussed in the next paragraph.

e) Student is asked to give comment about teaching is doing and about the reading.

f) The next stage be continue with part of reading/next paragraph, and chosen a student will make role as "teacher-student"

g) Student is trained/directed make role as "teacher-student" as long as the activity.

h) At the next days, as long as teacher decrease role in dialog, therefore "teacher- student" and the other student have self initiative to control the activity.

The other stage of Reciprocal Teaching Strategy, they are: ${ }^{10}$

1) Predicting: The leader asks the students to read the topic sentence or subheading and then predict what the rest of the paragraph will be about. Since the topic sentence tells what will follow, you can teach the students how to skim read at this point.

2) Reading: This card invites the students to read up to a certain point. They can read silently, to the group, to a partner or in unison, to add variety.

3) Clarifying: This card gives the readers the opportunity to have any unfamiliar words, locations or pronunciations 'made clear'. At first the students may not volunteer that they don't know something. So you might pick out a word or a place and ask the group to clarify it. If all members don't offer to answer the question, and then talk about

10 Edu, Lewin K, Teaching Reading and Viewing Strategies and Activities for Years, 1-9, (Melbourne Street South Brisbane: Queensland Studies Authority, 2008), p. 47-48. 
how the purpose of reading is to gain meaning and if we are not gaining meaning, then we are simply 'barking at the print'.

4) Questioning: Ask the students to generate the questions at this point. The questions can be answered orally or, depending on your purpose, you might like the group to record some of their questions and answers.

5) Summarizing: This is the perfect moment to teach key points, notetaking and to some extent paraphrasing.

6) Swap leaders: Passes leadership to another student.

\section{Description of Reading Comprehension}

a. Definition of Reading Comprehension

According to Douglas Brown that "reading is a process negotiating meaning; the reader brings to the text a set of schemata for understanding it, and it is take the product of that interaction" . ${ }^{11}$ According to Marilyn that "reading is one of the principal means of obtaining information. The information may be in printed form, such us a book magazine, or in electronic form on a computer screen. Reading is an efficient way to learn because it allows you to control the flow of information". ${ }^{12}$ Furthermore David Nunan States that "reading is a fluent process of readers combining information from a text and their own background knowledge to build meaning". ${ }^{13}$ While according to Kathleen that "reading, at first, may appear to be routine activity in which individual words are combined to produce meaning" ${ }^{14}$ So, reading is an activity to find out the information from the reading.

Reading is a receptive skill, it is transactional between a reader and writer, reading is an interactive process between a reader and the text. As a result a writer can communicate with a reader through a text, and also reading is an interactive process between the reader and text. "Reading is an essential skill for learners of English as a second language". For most of these learners, it is the most important skill to master in order to ensure

\footnotetext{
${ }^{11}$ Douglas Brown, Language Assessment, (USA: Longman, 2004), p. 189.

${ }^{12}$ Sue C. Camp. Marilyn L. Satterwhite, Collage and English Communication, (New York: Mc

${ }^{13}$ David Nunan, Practical English Language Teaching, (New York: Mc Graw Hill, 2003), p.

${ }^{14}$ Kathleen T. McWhorter, Efficient and Flexible Reading, (USA: Harper Collins Publisher,
} Green- Hill, 2003), p. 68. 68. 1992), p. 23. 
success not only in learning English but also in learning in any content class where reading English is required. With strengthened reading skills, learners will make greater progress and development in all areas of learning. Therefore, reading is a fluent process of reader combining information from a text or passage and their own background knowledge in bringing meaning to and getting meaning from printed or written material.

Actually reading a textbook is how reader can build a complete comprehension base on many words structurally in a text. And also the process must be routine to enrich our comprehension what the text tell about.

Further, Albert J. Haris states:

Reading is a complex cognitive process of decoding symbols in order to construct or derive meaning (reading comprehension). It is a means of language acquisition, of communication, and of sharing information and ideas. Like all language, it is a complex interaction between the text and the reader which is shaped by the reader's prior knowledge, experiences, attitude, and language community which is culturally and socially situated. The reading process requires continuous practice, development, and refinement. And then reading is the meaningful interpretation of written or printed verbal symbol. It can apply also to the interpretation of mathematical symbols, codes, and other symbolic systems. Beside that reading is extension of oral communication and built upon listening and speaking skills. ${ }^{15}$

So, reading is the readers' activities to get meaning or message from an author. An author ell the meaning or massage to reader in printed or written material ${ }^{16}$. If an author cannot build a complex meaning in a text, they reader will not understand what text tell about.

b. Types of Reading

There are some types of reading, they are: ${ }^{17}$ 1969), p. 3.

15 Albert J.Haris, How to Increase Reading Ability, (New York: David Mckay Company,

${ }_{16}$ Henry Guntur Tarigan, Membaca Sebagai Sebuah Keterampilan Berbahasa, (Bandung: Angkasa, 2005), p. 6. p. 67-69

${ }^{17}$ Ag. Bambang Setiyadi, Teaching as A Foreign Language, (Yogyakarta: Graha Ilmu, 2006), 
1) Choral Reading

2) Silent Reading

3) Intensive Reading

4) Extensive Reading

5) Supplementary Reading

c. Level of Comprehension

According to Friend and Bursuck, there are three levels of comprehension that must be achieved in reading comprehension, including analytical exposition text. ${ }^{18}$ They are:

1) Literal Comprehension

Reading for literal comprehension, which involves acquiring information that is directly stated in concerns in main ideas, details, causes and effect also sequences understanding vocabulary, sentences and paragraph meaning.

2) Interpretative Reading

Interpretative reading between lines or making inferences, it is the process of deriving ideas that are implied rather than directly stated. The skills of interpretative reading include:

a) Inferring the main ideas of passages in which the main ideas are not directly stated

b) Inferring cause and effect relationship when they are no directly stated

c) Inferring relevant adverb

d) Inferring relevant word

e) Inferring committed words

f) Detecting mood

g) Detecting the author's purpose in writing

h) Drawing conclusion

3) Critical Reading

The levels of critical reading comprehension are: the students can analyze, evaluate, and personally reaching to information presented in a passage. And also there are two abilities, namely personally reaching to information in a passage indicating its meaning to the

${ }_{18}$ M. Friend and W. Bursuck, Including Students with special needs: A practical guide for classroom teachers, (Boston: Allyn and Bacon, 2006), p. 177. 
reader an also analyzing and evaluating the quality of written information in terms of some standard. It can be concluded that critical reading includes the ability in:

a) Distinguishing between the fact and opinion

b) Evaluating the accuracy and the appropriateness of the information given in the text

c) Recognizing persuasive statement

d. Purposes of Reading

The main goals of reading are to get and find information include content and meaning of the text based on the purpose. ${ }^{19}$

Tarigan stated are some goals of reading such as:

1) Reading is for identifying important information.

2) Reading is for main ideas.

3) Reading is for finding the specific information.

4) Reading is for underlining the important information.

5) Reading is to classify the difficult word.

6) Reading is to evaluate.

7) Reading is to compare or contrast.

There are five purposes of reading, they are: ${ }^{20}$

1) Reading for Pleasure

2) Reading for Practical Application

3) Reading for General Ideas.

4) Reading to Locate Specific Information.

5) Reading to Critically Evaluate

According to Jeremy Harmer, there are several purposes of reading. He said that the purpose of reading is different in the way. It saw what kind of the text will be read. Next, there are the purposes or the reason for reading. ${ }^{21}$

1) Instrumental: a large amount of the reading takes place because it will help us to achieve some clear aim. Thus, for example, we read

${ }^{19}$ Henry Guntur Tarigan, Membaca sebagai... p. 9.

20 W. Royce Adams, Reading Skills A Guide for Better Reading, (London: Cambridge University, 1998), p. 8-11.

${ }^{21}$ Jeremy Harmer, The Practice of English Language Teaching (Third Edition Completely Revises and Update), (England: Longman, 2003), p.200-202. 
the road sign so that we know where to go. We read the instructions on the ticket because we need to know how to operate it.

2) Pleasurable: the people read magazine or spend hours buried in the Sunday paper, other go to poetry readings, read illustrated cartoon or photo-story.

3) For General Understanding: good reader is able to take in a stream of discourse and understand the gist of it without worrying too much about the details. Reading for such 'general' comprehension means not stopping for every word, not analyzing everything that the writer includes the text. It can use skimming.

4) For specific information: in contrast to reading for gist, we frequently go to written text because we want specific detail. Reading in this skill is frequently referred to as scanning.

5) For detail information: sometimes we read in order to understand everything we are reading in detail. This is usually the case with written instruction or direction, or with the description of scientific procedures, it happens when someone gives us the address and telephone number and we write down all the detail.

6) Interpreting text: reader is able to see beyond the literal meaning of word on the passage, using a variety of clues to understand what writer implying. Successful interpreting in this kind depends to a large extent on share schemata.

So, the researcher concludes the purpose of reading are to get or find the important information, finding specific information, and to evaluate reading. It have talked above that comprehension is ability to construct the language to take the information from the text.

e. Assessment of Reading Comprehension

Assessment as the act of collecting information an making judgments on a language learners' knowledge of a language and ability to use it. ${ }^{22}$ Any assessment of reading must begin with the purpose of the assessment. At least four major purposes for classroom-based assessment of reading have been identified:

1) Studying, evaluating, or diagnosing reading behavior.

2) Monitoring student progress.

${ }^{22}$ David Nunan, Practical English... p. 310. 
3) Supplementing and confirming information gained from standardized and criterion-referred text.

4) Obtaining information not available from other sources. ${ }^{23}$

Reading comprehension needs evaluation. Evaluation is broader concept than assessment it involves collecting and interpreting information (which will usually include assessment data) for making decision about the effectiveness of a particular program. In assessing reading comprehension, the teacher can give test to students.

There are many kinds of test, they are:

1) Reading aloud

2) Multiple choices

3) Matching tasks

4) Gap-filling tasks

5) Short answer task

A reading passage is presented, and the test taker reads questions that must be answered, usually in written form, in a sentence or two. ${ }^{24}$

So, the researcher uses the five indicators above for assessment of reading and chooses multiple choices for test in this research.

\section{Definition of Narrative Text}

a. Definition of Text

Text is forms a piece of language use or a record of a communicative act, or the so called language which is functional. In general, texts which have the same sorts of meaning or the same structural elements are said to be the same text type.

According to American Heritage Dictionary Text is a subject referring to a topic and is a noun refers to: ${ }^{25}$

1) The original words of something written or printed, as opposed to a paraphrase, translation, revision, or condensation.

2) The words of a speech appearing in print.

3) Words, as of a libretto, that are set to music in a composition.

4) Words treated as data by a computer.

\footnotetext{
${ }^{23}$ Michel O' Malley and Lorraine Valdes Pierce, Authentic Assessments for English Language Learners, (USA: Wesley Publishing, 1996), p. 99.

24 Douglas Brown, Language Assessment Principle and Classroom Practices, (Pearson Longman: Priyanuada Abeywickrama), p. 230-247.

25 Adeulfayani, "Narrative Text" retrieved http//:www.answers.com/topic/text, accessed on Sunday, 17th May 2015.
} 
5) The body of a printed work as distinct from headings and illustrative matter on a page or from front and back matter in a book.

6) One of the editions or forms of a written work: After examining all three manuscripts, he published a new text of the poem.

7) Something, such as a literary work or other cultural product, regarded as an object of critical analysis.

8) A passage from the Scriptures or another authoritative source chosen for the subject of a discourse or cited for support in argument.

9) A passage from a written work used as the starting point of a discussion.

10) A text book.

So, the researcher concluded that text is the original words or a passage from a written work as opposed to a paraphrase, translation, revision, or condensation.

b. Kinds of Text

There are many kinds of text learnt by students of Junior High School in learning the reading skill like narrative, descriptive, recount and procedure text. According to Djuharie, kinds of text are narrative, description, report, explanation, discussion, procedure, spoof, recount, anecdote, news item and exposition. ${ }^{26}$

c. Narrative Text

Narrative is any written English text in which the writer wants to amuse, and to deal with actual or vicarious experience in different way. ${ }^{27}$ It is made to separate an experience past time that problematic, entertain and give moral value to the readers. ${ }^{28}$ A.S Hornby in Oxford Advanced Learner's Dictionary defines: "Narrative text is a description of events. ${ }^{29}$ Then, according to David

${ }^{26}$ Otong Setiawan Djuharie, Genre Dilengkapi 700 Soal Uji Pemahaman, (Bandung: CV. Yrama Widya, 2007), p. 39.

27 Sanggam Siahaan \& Kisno Shinoda, Generic Text Structure, (Pematang Siantar: Graha Ilmu, 2008), p. 73.

${ }^{28}$ Pardiyono, Pasti Bisa! Teaching Genre-Based Writing, (Yogyakarta: Penerbit Andi, 2007), p. 102

${ }^{29}$ AS Hornby, Oxford Advanced Learner's Dictionary ,(USA: Macmillan, 1991), p. 286. 
264 | TAZKIR: Jurnal Penelitian Ilmu-ilmu Sosial dan Keislaman

Vol. 03 No. 2 Desember 2017

Butt "Narrative is to construct a pattern of events with a unexpected outcome that entertain and instructs the reader or listener". ${ }^{30}$ So, narrative text is an event or moment that has occurred in the past time.

The basic purpose of narratives is to entertain, i.e. to gain and hold the reader's interest in a story. Similarly Pardiyono says that narrative text has purpose to amuse or entertain and gives good lesson to us and the other people who listen about narrative. ${ }^{31}$

There are many types of narrative text. They are typically imaginary but can be factual. They include fairy stories, mysteries, science fiction, choose-your-own- adventure, romance, horror stories, parables, fables and moral tales, myths and legends, and historical narratives. ${ }^{32}$

According to Otong Setiawan Djuharie, the language elements used in writing narrative text are noun, individual participant, past tense, conjunction, action verb, and saying verb.

Language Features

There are some language features in Narrative text, they are:

1) Certain nouns, pronouns, animals, and certain things in the story, such as maid, stepsisters, housework, etc.

2) Adjectives extending noun phrases, such as long black hair, two red apples, etc.

3) Time connectives and conjunctions to make events sequence, such as then, before that, soon, next, etc.

4) Adverbs and adverbial phrases to show location and time of events, such as here, in the mountain, happily ever after, etc.

5) Action verbs in past tense: stayed, climbed, jumped, etc.

6) Saying verbs indicating utterance such as said, told, promised, and thinking verbs identifying the thought, perception or feeling of the characters in the story, such as thought, understood, felt,

${ }^{30}$ David Butt and et al, Using Functional Grammar, (Sydney: MacQuarie University, 2003), p. 217.

${ }^{31}$ Pardiyono, Teaching Genre-Based Writing, (Yogyakarta: Andi OFFSET, 2007), p. 94.

32 Beverly Derewianka, Exploring How Texts Work, (Australia, Primary English Teaching Association, 1946), p. 40 
seemed, etc.

7) The use of Past Tense ${ }^{33}$

There are some indicators for reading comprehension in narrative, they are:

\begin{tabular}{|c|l|}
\hline No & \multicolumn{1}{|c|}{ Indicators of Reading Comprehension } \\
\hline 1. & Identifying topic sentence \\
\hline 2. & Identifying main idea \\
\hline 3. & Identifying supporting sentence \\
\hline 4. & Identifying conclusion \\
\hline 5. & Identifying vocabulary \\
\hline
\end{tabular}

d. Teaching of Narrative Text through Reciprocal Teaching Strategy

According to Harmer, the principles behind the teaching of reading are:

1) reading is not a passive skill,

2) students need to be engaged with what they are reading,

3) students should be encouraged to respond to the content of a reading text,

4) not just to the language,

5) prediction is a major factor in reading,

6) match the task to the topic and good teachers exploit reading texts to full. ${ }^{34}$

So, it means that reading is not an easy task. Teaching reading for most teacher especially narrative text is also not easy. That is why teacher should use the suitable strategy of learning. Reciprocal teaching strategy will be alternative way to make students easier in comprehension and reading narrative text

By combining Reciprocal teaching strategy and teaching reading (genres) as processes in teaching narrative text, it is hoped that students will be able to comprehension narrative text easily.

${ }^{33}$ Sanggam Siahaan \& Kisno Shinoda, Generic Text... p. 74.

${ }^{34}$ Jeremy Harmer, How to Teach English, (London: Logman, 1998), p. 70. 
266 | TAZKIR: Jurnal Penelitian Ilmu-ilmu Sosial dan Keislaman

Vol. 03 No. 2 Desember 2017

\section{RESEARCH METHODOLOGY}

This research was taken at SMP Negeri 5 Panyabungan. It is located on Bukit Barisan Street, No. 34 Panyabungan. The process of this research was held from March 2015 up to December 2015.

This study is conducted by using an experimental research design. According to John W. Creswell, "Experimental research included true experiment with the random assignment of subject to treatment condition as well as quasi experiment that use nonrandomized." 35 According to Suharsimi Arikunto, "Experiment is a way to find a causal relationship (casual relationship) between the two factors that intentionally inflicted by researchers with reduce or set aside other factors that could interfere" ${ }^{36}$ Next, according to Gay and Airasian, "Experimental research is the only type of research that can test hypotheses to established cause and effect". ${ }^{37}$

The experimental research was a kind of research which has the aim to know causal effect relationship between one variable and more to other variables. ${ }^{38}$ The experimental research controls the selection of participant for the study and divides the select participant in to more groups having similar characteristics at the start of experiment.

\section{POPULATION AND SAMPLE}

1. Population

The population is the group at interest to the research, the group to which she or he would like the result of the study to be generalization. ${ }^{39}$ According to Encyclopedia of Education says:" A population is a set (or collection) of all elements possessing one or more attributes of interest." ${ }^{40}$ Next, according to Gay and Airasian, "Population is the group of interest to the researcher, the group to which she or he would like the results of the study to be

${ }^{35}$ John W. Creswell, Research Design, (USA: Sage Publication, 2002), p. 14.

${ }^{36}$ Suharsimi Arikunto, Prosedur Penelitian Suatu Pendekatan Praktik, (Jakarta: Rineka Cipta, 1993), p. 3.

${ }^{37}$ L. R. Gay and Peter Airasian. Educational Research, (USA: Merril, 2000), p. 367.

${ }^{38}$ Ahmad Nizar, Metode Penelitian Pendidikan, (Bandung: Cita pustaka Media, 2014), p. 75.

39 L. R. Gay and Peter Airasian, Educational Research Competencies for Analysis and Application, (New Jersey: Prentice - Hill, Inc, 1992), p. 122.

40 Suharsimi Arikunto, Prosedur Penelitian Suatu Pendekatan Praktik, (Jakarta: PT Rineka Cipta, 2006), p. 130. 
generalizable" ${ }^{41}$ The last, Ary said that population is all members of well defined class of people, event, or objects. ${ }^{42}$

Based on the explanation above, the population of the research was all the students of SMP Negeri 5 Panyabungan at IX Grade. The population of research consists of 8 classes with 161 students.

2. Sample

According to Arikunto says: "Sample adalah sebagian atau wakil populasi yang diteliti". ${ }^{43}$ Then, according to Gay and Airasian, "Sample comprises the individuals, items, or events selected from a larger group referred to as a population". ${ }^{44}$ In this research, withdrawal of the sample by using cluster sampling. Each element in population had equal opportunities to choose. The researcher was decided two classes total 41 students as sample. Two classes divided as experimental class (IX-1) consists of 22 people, and control class (IX-2) consists of 19 people.

3. Instrument of Collecting Data

The instrument for collecting data is test. The designs of the reading test are in the form of multiple Choice, True/False, Matching, Gapped tests, and Proofreading, particularly on reading fiction. In this case, writer chose Multiple Choice as test. Cyril says, "a multiple choice questions (MCQs) is test item usually set out in such a way that the candidate is required to select the answer from a number of given options, only one of which is correct. ${ }^{45}$. The test is aimed at collecting data supporting the students' reading comprehension in narrative text.

4. Indicator of Test

The test is divided in two parts. First is pre test consist of 25 number and the second is post test consist of 25 number. The test gives to both groups. To find out the scores of the students' answer, the writer gives 4 score for each item. Thus, the maximum score of test is 100 .

\footnotetext{
${ }^{41}$ L. R. Gay and Peter Airasian, Educational Research... p. 122.

${ }^{42}$ Sukardi, Metodologi Penelitian Pendidikan, (Jakarta: Bumi Aksara, 2003), p. 53.

${ }^{43}$ Suharsimi Arikunto, Prosedur Penelitian... p. 131.

${ }^{44}$ L. R. Gay and Peter Airasian, Educational Research... p. 121.

${ }^{45}$ Cyril J. Weir, Communication Language Teaching, (New York: Prentice Hall, 1990), p. 43.
} 


\section{VALIDITY AND RELIABILITY INSTRUMENT}

1. Validity

Validity is the most important quality of a test. It is the degree to which a test measures what it is supposed to measure, and consequently, permits appropriated interpretations of test scores. ${ }^{46}$

In this research, the researcher used item validity to get the validity of instrumentation. Item validity is a part of the test as a totality to measure the test by items. Then, the test consists of 60 multiple-choice tests that divided in to two groups. They were 30 for pre-test and 30 for post-test.

To know the validity of the each question will be refer to list $r$ biserial with $r$ in 5\% significant: 0,349 and 1\% significant: 0,449 . So, if $r$ accoun $>r$ table the test is classified valid.

So, to get the validity of the test, the formula of $r$ pointbiserial can be used as follow:

Where:

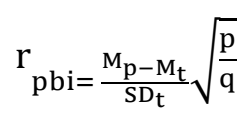

$$
\begin{array}{ll}
\mathrm{r}_{\mathrm{pbi}} & : \text { coefficient item validity } \\
\mathrm{M}_{\mathrm{p}} & : \text { mean score of the total sore } \\
\mathrm{SD}_{\mathrm{t}} & : \text { Standard Deviation of the total score } \\
p & : \text { presentation of the right answer of the item tested validity. } \\
q & : \text { presentation of the wrong answer of the item tested validity. }
\end{array}
$$

2. Reliability of Pre-test

Reliability was the extent to which measuring device was consistent in measuring whatever it measures. It refers to the consistency of measurement that was to how consistent scores or other evaluation results were from one measurement to another. To get the reliability of the test, the Kuder Richardson 20 Formula (KR01) was applied with r table 0.70.

Criteria of test reliability are as follows: ${ }^{47}$

$$
\begin{aligned}
& \mathrm{r}_{11}=0.70 \quad \text { high correlation } \quad \text { (reliable) } \\
& \mathrm{r}_{11}>0.70 \quad \text { high correlation (reliable) } \\
& \mathrm{r}_{11}<0.70 \quad \text { low correlation } \quad \text { (reliable) } \\
& \mathrm{R}_{11}=\left(\frac{n}{n-1}\right)\left(\frac{s_{t^{2}}-\sum p q}{s_{t^{2}}}\right)
\end{aligned}
$$

${ }^{46}$ L. R. Gay and Peter Airasian, Educational Research... p. 191.

${ }^{47}$ Anas Sujono, Pengantar Stratistik Pendidikan, (Jakarta: PT Raja Grafindo, 2005), p. 209. 
In Which:

$\mathrm{R}$ : Reliability of the Instrument

$\mathrm{n}$ : Number of the Test

$\mathrm{St}^{2}$ : Variants total

$\mathrm{p}$ : Proportion subject who is right answer

q : Proportion subject who is wrong answer

\section{TECHNIQUE OF DATA ANALYSIS}

\section{Qualification Test of Data Analysis Pre-test and Post-test}

a. Normality test

Based on the result of calculation, the score of experimental class $\mathrm{Lo}=0.033<\mathrm{Lt}=0.173$ with $\mathrm{n}=22$ and control class $\mathrm{Lo}=0.032<\mathrm{Lt}=0.195$ with $\mathrm{n}=19$, real level $\alpha$ was 0.05 . Cause Lo $<\mathrm{Lt}$ in the both class. So, $\mathrm{H}_{\mathrm{o}}$ is accepted, it means that experiment class and control class were distributed normal. Researcher calculation, it can be seen on the appendix 25 and table liliefors on the appendix 32.

b. The homogeneity of test

Based on the result of calculation, the coefficient of $F$ count $=$ is compared with $\mathrm{F}_{\text {table. }}$ Where $\mathrm{F}$ table was determined at real $\alpha=0.05$, and the same numerator $\mathrm{dk}=\mathrm{N}-1=22-1=21$ and denominator $\mathrm{dk} \mathrm{N}-1=19-1=18$ So, by using the list of critical value at $F$ distribution is got $F \quad 0,05(21,18)=$ 2.11. It shows that score of experimental class $F$ count $(1.51)<F$ table $(2.11)$ and score of control class $\mathrm{F}$ count $(1.62)<\mathrm{F}$ table $(2.11)$. So, it can be concluded that the variant from the data of the effect of reciprocal teaching strategy on students' reading comprehension in narrative text at grade IX of SMP N 5 Panyabungan by experimental and control class was homogeny.

\section{THE RESULT OF THE RESEARCH}

For analyzing the data, researcher collected the data and gave the test about reading comprehension to the sample. The sample of this research was class IX-1 for experimental class and class IX-2 for control class. The test was divided into two aspect, they were pre-test and post-test. Pre-test was done before conducted the treatment and post- test was done after conducted the treatment. Researcher applied quantitative analysis by used the formulation of $t$ - 
270 | TAZKIR: Jurnal Penelitian Ilmu-ilmu Sosial dan Keislaman

Vol. 03 No. 2 Desember 2017

test. It was done to know the significant effect of using reciprocal teaching strategy on students' reading comprehension in narrative text. Then, researcher would describe the result based on the data that had been researched as follow.

1. Description of Data Before and After Using Reciprocal Teaching Strategy in Experimental Class

The total score of experiment class in pre-test was 5884, mean was 49 , standart deviation was 9.56, varians was 91.40, median was 49 , range was 32 , modus was 47.15, interval was 6 . The researcher got the highest score was 72 and the lowest score was 40 . Next, the calculation of how to get it could be seen in the appendix 20. The total score of experiment class in post-test was 1636, mean was 73.09 , median was 73.64 , mode was 74.83 , range was 32 , interval was 6 , standart deviation was 67.32 , varians was 8.20 . The researcher got the highest score was 92 and the lowest score was 60 . Next, the calculation of how to get it could be seen in the appendix 21 .

2. Description of Data Before and After Using Reciprocal Teaching Strategy in Control Class

The total score of control class in pre-test was 856, mean was 54.36, median was 54.84 , mode was 56.3 , range was 36 , interval was 7 , standart deviation was 11.77, varians was 138.69. The researcher got the highest score was 65 , and the lowest score was 35.(See appendix 21). The table above the total score of control class in post-test was 1246, mean was 63.78, standart deviation was 10.44 , varians was 109.17 , median was 57.33 , mode was 62 , range was 36, interval was 7 . The researcher got the highest score was 88 and the lowest 52 score was. Next, the calculation of how to get it could be seen in the appendix 23.

3. Technique of Data Analysis

1. Qualification Test of Data Analysis Pre-test and Post-test a. Normality of experimental class and control class in Pre-test

Based on the table above researcher calculation, the score of experiment class $\mathrm{Lo}=0.033<\mathrm{Lt}=0.173$ with $\mathrm{n}=22$ and control class $\mathrm{Lo}=$ $0.032<\mathrm{Lt}=0.195$ with $\mathrm{n}=19$, and real level $\alpha 0.05$. Cause $\mathrm{Lo}<\mathrm{Lt}$ in the both class. So, $\mathrm{H}_{\mathrm{o}}$ is accepted, it means that experiment class and control class were distributed normal. Researcher calculation, it can be seen on the appendix 25 and appendix 26.

b. Homogenity of experimental class and control class in Pre-test 
Then, the coefficient of $\mathrm{F}$ count $=$ is compared with $\mathrm{F}$ table. Where $F$ table was determined at real $\alpha=0.05$, and the same numerator $\mathrm{dk}=\mathrm{N}-1=22-1=21$ and denominator $\mathrm{dk} \mathrm{N}-1=19-1=18 \mathrm{So}$, by using the list of critical value at $F$ distribution is got $F \quad 0.05$ (21.18) $=2.10$. It shows that $F_{\text {count }}(1.51)<F_{\text {table }}$ (2.10). So, it can be concluded that the variant from the data of the effect of using reciprocal teaching strategy on students' reading comprehension in narrative text at grade IX of SMP N 5 Panyabungan by experimental and control class was homogeny.

c. Normality of experimental class and control class in Post-test

Based on the table above researcher calculation, the score of experimental class $\mathrm{Lo}=-0.214<\mathrm{Lt}=0.173$ with $\mathrm{n}=22$ and control class $\mathrm{Lo}=0.03<\mathrm{Lt}=0.195$ with $\mathrm{n}=19$, real level $\alpha$ was 0.05 . Cause Lo $<\mathrm{Lt}$ in the both class. So, $\mathrm{H}_{\mathrm{o}}$ is accepted, it means that experiment class and control class were distributed normal. Researcher calculation, it can be seen on the appendix 27 and appendix 28 .

d. Homogeneity of experimental class and control class in Post-test

Then, the coefficient of $\mathrm{F}$ count $=$ is compared with $\mathrm{F}$ table. Where $\mathrm{F}$ table was determined at real $\alpha=0.05$, and the same numerator $\mathrm{dk}=\mathrm{N}-1=22-1=21$ and denominator $\mathrm{dk} \mathrm{N}-1=19-1=18$ So, by using the list of critical value at $\mathrm{F}$ distribution is got $\mathrm{F}_{0,05(21,18)}=2.10$. It shows that $F_{\text {count }}(1.62)<F_{\text {table }}(2.10)$. So, it can be concluded that the variant from the data of the effect of using reciprocal teaching strategy on students' reading comprehension in narrative text at grade IX of SMP N 5 Panyabungan by experimental and control class was homogeny.

\section{Hypothesis Test}

The hypothesis of research "Using Reciprocal Teaching Strategy has significant effect on students' reading comprehension in narrative text at grade IX of SMP N 5 Panyabungan". Based on the data collected, the data will be analyzed to prove hypothesis by using formula of T-test, see appendix 24 .

Hypothesis of research was using Reciprocal Teaching Strategy had significant effect on students' reading comprehension in narrative text at grade IX of SMP N 5 Panyabungan. The researcher took the decision of criteria in doing this research. Hypothesis was accepted since t observed 
$>t$ table of significant and the degree of freedom $(\mathrm{df})=\left(\mathrm{n} 1+\mathrm{n}_{2}-2\right)=22+19$ $-2=39$.

From the calculation of $\mathrm{t}$-test, it was found that $\mathrm{t}$ observed is higher than $t$ table $(2.75>1.68)$.So that, from the calculation above, it was concluded that the result of experimental wass significant, next reciprocal teaching strategy had significant effect on students' reading comprehension in narrative text at grade IX of SMP N 5 Panyabungan. So, the hypothesis was accepted.

\section{CONCLUSION}

Based on the result of the research and calculations of the data, the researcher got the conclusion that using reciprocal teaching strategy had the effect on students' reading comprehension in narrative text at grade IX of SMP N 5 Panyabungan. It could be seen from the mean score of experimental and control class $(73.09>63.78)$ and the calculation of $t_{\text {account }}>t_{\text {table }}(2.75>1.68)$. Hypothesis was accepted. So, reciprocal teaching strategy had significant effect on students' reading comprehension in narrative text at SMP Negeri 5 Panyabungan.

The result of this study showed that the use of herringbone technique has the effect on students' reading comprehension. Therefore, the following suggestions are offered:

1. The researcher on this occasion hoped that other researchers would conduct a research related to the topic of this study, further, especially to find out other strategy on students' reading comprehension in narrative text.

2. The Principal of SMP Negeri 5 Panyabungan, to motivate the teacher, especially English teachers to teach as well as possible by maximizing the using of reciprocal in teaching, because reciprocal teaching strategy can be used as an alternative way of teaching in teaching reading.

3. For the teacher, it is very wise to use reciprocal teaching strategy in reading because this strategy can stimulate students to have motivation especially in reading.

4. Other researcher, the findings of this research were subject matters which can be developed largely and deeply by adding other variables or enlarge the samples. 


\section{REFERENCES}

Adams, W. Royce, Reading Skills A Guide for Better Reading, London: Cambridge University, 1998.

Abdurrahman Mulyono. Pendidikan Bagi Anak yang Berkesulitan Belajar. Jakarta: Rineka Cipta, 1999.

Ahmad Nizar. Metode Penelitian Pendidikan. Bandung: Citapustaka Media, 2014.

Ali, Abdul Yusuf. The Meaning of the Holy Quran in the English Language. AlAlami Publications: Beurit, 2001.

Anas Sujono. Pengantar Statistik Pendidikan. Jakarta: PT Raja Grafindo, 2005.

Brown, Douglas. Language Assessment Principle and Classroom Practices. Pearson Longman: Priyanuada Abeywickrama. Language Assessment. USA: Longman, 2004.

Burhan Bungin,. Metodologi Penelitian Kuantitatif. Surabaya: Prenada Media, 2005.

Camp, Sue C. Marilyn L. Satterwhite. Collage and English Communication. New York: Mc Green- Hill, 2003.

Creswell, John W. Research Design. USA: Sage Publication, 2002.

Derewianka, Beverly. Exploring How Texts Work. Australia, Primary English Teaching Association, 1946.

Friend M. and W. Bursuck. Including Students with special needs: A practical guide for classroom teachers. Boston: Allyn and Bacon, 2006.

Gay L. R. and Peter Airasian.Educational Research Competencies for Analysis and Application. New Jersey: Prentice - Hill, Inc, 1992. . Educational Research. USA: Merril, 2000.

Hornby, AS. Oxford Advanced Learner's Dictionary. USA: Macmillan, 1991. .Oxford Advanced Learners Dictionary. New York: Oxford University Press, 2000.

J. Haris, Albert. How to Increase Reading Ability. New York: David Mckay Company, 1969. 
274 | TAZKIR: Jurnal Penelitian Ilmu-ilmu Sosial dan Keislaman

Vol. 03 No. 2 Desember 2017

Lewin K, Edu. Teaching Reading and Viewing Strategies and Activities for Years, 1-9, Melbourne Street South Brisbane: Queensland Studies Authority, 2008.

Malley, Michel O and Lorraine Valdes Pierce. Authentic Assessments for English Language Learners. $\quad$ USA: Wesley Publishing, 1996.

McWhorter, Kathleen T. Efficient and Flexible Reading. USA: Harper Collins Publisher, 1992.

Nunan, David. Practical English Language Teaching. New York: McGraw Hill, 2003

Pardiyono. Teaching Genre-Based Writing. Yogyakarta: Andi OFFSET, 2007.

. Pasti Bisa! Teaching Genre-Based Writing. Yogyakarta: Penerbit Andi, 2007.

Patel, M.F. \& Praveen M. Jain. English Language Teaching (Methods, Tools, E Technique. Jaipur: $\quad$ Sunrise Publishers \& Distributers.

Otong Djuharie Setiawan, Genre Dilengkapi 700 Soal Uji Pemahaman. Bandung: CV. YramaWidya, 2007.

Siahaan, Sanggam \& Kisno Shinoda. Generic Text Structure. Pematang Siantar: Graha Ilmu, 2008.

Suharsimi Arikunto. Prosedur Penelitian Suatu Pendekatan Praktik. Jakarta: PT Rineka Cipta, 2006.

Sukardi. Metodologi Penelitian Pendidikan. Jakarta: Bumi Aksara, 2003.

Tarigan, Henry Guntur. Membaca Sebagai Sebuah Keterampilan Berbahasa. Bandung: Angkasa, 2005

Trehearne, Miriam P. and Roz Doctorow. Reading Comprehension: Strategies That Work. Newark: DE International Reading Association, 2000.

Trianto. Mendesain Model Pembelajaran Inovatif - Progresif. Jakarta: Kencana Prenada Media Group, 2009.

Wainwright, Golden. Speed Reading Better Recalling. Jakarta: Gramedia, 2007. 